\title{
PENGENDALIAN ALTERNATIF HAMA SERANGGA SAYURAN DENGAN MENGGUNAKAN PERANGKAP KERTAS
}

\section{ALTERNATIVE CONTROL OF INSECT IN VAGATABLE CROPS USING TRAPPING PAPER MEDIA}

\author{
Lukmanul Hakim ${ }^{1}$, Erdi Surya ${ }^{2}$, dan Abdul Muis ${ }^{1}$ \\ ${ }^{1}$ Jurusan Teknologi Pangan, Fakultas Teknologi Pertanian \\ 2Jurusan Biologi, Fakultas Keguruan dan Ilmu Pendidikan \\ Universitas Serambi Mekkah, Banda Aceh 23245, Indonesia \\ Korespondensi : lukmanulhakim@serambimekkah.ac.id \\ Diterima 30 September 2016 / Disetujui 20 Oktober 2016
}

\begin{abstract}
ABSTRAK
Sayuran merupakan bahan pangan yang sangat dibutuhkan manusia karena mengandung serat dan sejumlah vitamin dan mineral. Untuk memenuhi kebutuhan masyarakat akan sayuran banyak kendala yang dihadapi petani, salah satunya adalah gangguan hama serangga. Untuk mengendalikan hama serangga telah banyak pula cara yang dilakukan oleh petani. Penelitian ini bertujuan untuk menguji model perangkap serangga yang terbuat dari media kertas dan lampu warna. Warna yang dicobakan dalam penelitian ini terdiri dari merah, kuning, dan hijau. Penelitian ini telah dilakukan dari bulan Juli sampai dengan Agustus 2016 di kebun percobaan Sekolah Menengah Kejuruan Pembangunan Pertanian (SMKPP), Kecamatan Lembah Seulawah, Kabupaten Aceh Besar, Provinsi Aceh. Objek penelitian adalah tanaman jagung. Metode penelitian menggunakan RCBD dengan 3 perlakuan dan 4 ulangan. Variabel pengamatan populasi serangga yang terperangkap pada media kertas dan lampu warna. Hasil penelitian menujukkan tangkapan serangga tertinggi pada kertas dan lampu warna kuning, kemudian diikuti kertas dan lampu warna hijau dan merah.
\end{abstract}

Kata kunci : Alternatif Pengendalian, Perangkap Warna, Sayuran

\begin{abstract}
This study aimed to test the two models of trap insect, which were made from trapping paper media and colored light. The tested colors are red, yellow, and green, while the colors of light consist of red, yellow, and green. This study conducted from July to August 2016 at the experimental field of "Hight School Vocational Agricultural Development" Seulawah Valley Districts, Large Districts of Aceh, Aceh Province using the corn crop as the object. The research method approached in Randomized Completely Block Design (RCBD) with 3 treatments and 4 replications. The variable observation was insect populations trapped on paper media and colored light. The result showed that the highest insect population was on paper and yellow color light, the medium population was on the green paper, and the lowest population encountered on red paper.
\end{abstract}

Keywords : Alternatif Control, Color Trapping, Vegetable Crops 


\section{PENDAHULUAN}

Serangga merupakan kelompok hewan yang dominan di muka bumi dengan jumlah spesies hamper $80 \%$ dari jumlah hewan yang ada di permukaan bumi (Borror, 1987). Dengan demikian sangatlah beralasan bahwa serangga berhasil dalam mempertahankan keberlangsungan hidupnya pada habitat yang bervariasi, dengan kapasitas reproduksi yang tinggi, jenis makanan yang bervariasi dan kemampuan adaptasi yang tinggi (Kalshoven, 1981).

Serangga dapat hidup dalam sebuah ekosistem pertanian secara berkelanjutan, karena pada ekosistem ini serangga dapat memperolah makanan yang cukup. Ekosistem menurut Andrewartha dan Birch (1961) adalah sistem yang terbentuk oleh interaksi dinamik antara komponenkomponen abiotik dan biotik. Dengan demikian, maka ekosistem dapat didefinisikan sebagai suatu kesatuan yang rumit dan interaktatif yang tersusun oleh semua organisme yang hidup pada suatu daerah dengan lingkungannya. Atas dasar pengertian tentang penjenjangan sistem kehidupan tersebut, maka untuk pengelolaan hama diperlukan analisis interaksi sistem sampai pada aras ekosistem (Kasumbogo, 1984).

Penggunaan media kertas dan lampu warna merupakan suatu upaya pengendalian serangga hama secara alternatif. Ketertarikan serangga terhadap warna adalah salah satu cara adaptasi serangga di alam. Adaptasi ini dapat terjadi pada serangga dengan tujuan melindungi dirinya dari gangguan predator. Penelitian ini diharapkan dapat memberikan jalan alternatif dalam pengelolaan serangga hama yang merusak sayuran dan diharapkan juga untuk menekan peng- gunaan insektisida kimia secara terus menerus. Penelitian ini untuk memperkenalkan salah satu model alat perangkap serangga yang terbuat dari media kertas dan lampu warna untuk memberikan daya tarik secara fisik.

Ketertarikan serangga terhadap warna dapat dijadikan acuan untuk usaha pengendalian, penggunaan perangkap kertas dan lampu berwarna merupakan salah satu cara untuk monitoring serangga di lapangan, sehingga memudahkan dalam melakukan identifikasi di laboratorium. Dari beberapa literatur menyebutkan bahwa ketertarikan serangga terhadap warna merupakan perilaku serangga di alam. Pendekatan terhadap perilaku serangga dapat dijadikan acuan dasar penelitian. Banyak cara yang dapat dilakukan untuk memberi daya tarik serangga terhadap warna. Salah satunya adalah dengan memasang kertas warna-warni yang diberikan perekat. Warna media yang digunakan harus dapat memberi pantulan cahaya atau adanya zat penarik (Sihombing et al., 2013).

Serangga sebagai hama tanaman perlu dikendalikan untuk tidak menimbulkan kerusakan yang berdampak pada turunnya produktivitas (Abdullah dan Rauf, 2011). Berbagai cara telah dilakukan untuk menurunkan tingkat kerusakan pada tanaman disebabkan serangga, seperti pengendalian secara mekanis, fisik, bercocok tanam, dan menggunakan agensia hayati (Debeach, 1979). Pengen-dalian secara fisik adalah menggunakan gaya fisika, seperti perangkap mekanis, dengan menggunakan hormon dan zat pemikat (Braham, 2014). Salah satu pengendalian alternatif yang telah diujicobakan dalam penelitian ini adalah dengan menggunakan 
media kertas warna dan lampu warna sebagai perangkap mekanik.

Penggunaan perangkap mekanik dari bahan media kertas akan membantu petani dalam mengurangi gangguan hama serangga pada sayuran. Menurut hasil penelitian Thamrin dan Asikin (2003), dengan menggunakan plastik kuning efektif menarik lalat pemakan daun sebanyak 24 ekor rata-rata dalam seminggu. Pengujian perangkap warna dengan penambahan feromon sex dapat dilakukan untuk menjebak hama Tryporiza insartulas pada tamanan padi (Hendarsih dan Usyati, 1999).

Penelitian ini akan memformulasikan dan menerapkan model alat perangkap yang terbuat dari media kertas dan lampu warna untuk memikat serangga yang merusak tanaman sayuran.

\section{BAHAN DAN METODE}

Penelitian ini menggunakan kertas dan lampu warna sebagai alat perangkap serangga secara mekanis, yang terdiri dari:

\section{Perangkap kertas warna}

Untuk menangkap serangga pada siang hari menggunakan perangkap kertas warna yang digunakan dalam penelitian ini adalah kertas warna merah, warna kuning, dan warna hijau yang diberikan lem perekat pada bagian permukaan. Sebagaimana hasil penelitian terdahulu tentang peng-gunaan zat pemikat (attractant) pada media kertas untuk memberikan daya tarik serangga (Marikun et al., 2014). Pemberian jaring warna untuk mencegah infestasi hama pada tanaman cabe (Utami et al., 2014). Penggunaan perangkap warna berperekat dan aroma rempah untuk mengendalikan hama gudang (Rahayu et al., 2013). Perangkap warna berperekat untuk memonitoring dan evaluasi populasi hama tembakau (Sihombing et al., 2013).

\section{Perangkap lampu warna}

Sedangkan untuk pengamatan serangga malam hari menggunakan lampu perangkap warna merah, kuning, dan hijau yang dilapisi dengan lem perekat pada permukaan lampu. Pemasangan alat perangkap sangat menguntungkan petani karena dapat mengirim gambar serangga untuk analisis lebih lanjut dan tujuan monitoring (Thangalakshmi dan Ramanujan, 2015). Penggunaan perangkap cahaya merupakan salah satu pengendalian serangga hama klasik telah banyak dilakukan oleh orang terdahulu (Reddy dan Ammika, 2015). Pengendalian serangga dengan menggunakan lampu perangkap merupakan cara tertua (Augul et al., 2015). Penggunaan perangkap berbasis tenaga surya akan sangat baik untuk memikat serangga hama pada sayuran (Sermsri dan Chonmapat, 2015).

\section{Variabel pengamatan}

Yang diamati dari kegiatan penelitian ini adalah jumlah populasi serangga yang terperangkap pada media kertas dan lampu warna. Untuk selanjutnya semua populasi yang tertangkap dilakukan identifikasi mulai dari Ordo, Family, dan Species (Borror, 1987).

\section{Metoda penelitian}

Penelitian ini menggunakan Randomized Complete Block Design ( $\mathrm{RCBD}$ ) yang terdiri dari 3 perlakuan dan 4 ulangan (Gomez dan Gomez, 1995) masing-masing perlakuan terdiri dari 3 jenis kertas warna, yaitu kertas warna merah (M), kertas kuning (K), kertas hijau (H) dan lampu warna merah, kuning, dan hijau. Untuk masing-masing perlakuan 
dilakukan 4 kali pengulangan. Penelitian ini telah dilaksanakan di kebun percobaan Sekolah Menengah Kejuruan Pembangunan Pertanian (SMKPP), Kecamatan Lembah Seulawah, Kabupaten Aceh Besar, Provinsi Aceh dari bulan Juli sampai Agustus 2016. Data dianalisis menggunakan Analysis of variance (Anova) dengan membandingkan $\mathbf{F}_{\text {hitung }}$ dengan $\mathbf{F}_{\text {table }}$ pada skala $0,05 \%$. Bila keduanya berbeda sangat nyata dilanjutkan Uji Least Significant Difference (LSD) pada taraf $\alpha 0,05 \%$.

\section{HASIL DAN PEMBAHASAN}

\section{Pengamatan siang hari}

Hasil pengamatan menunjukkan bahwa jumlah dan jenis serangga yang tertangkap pada media kertas warna menunjukkan populasi serangga tertinggi pada perlakuan kertas warna kuning 23,25 populasi diikuti oleh kartas warna hijau 7,50 populasi, dan kertas warna merah 6,00 populasi (Gambar 1).

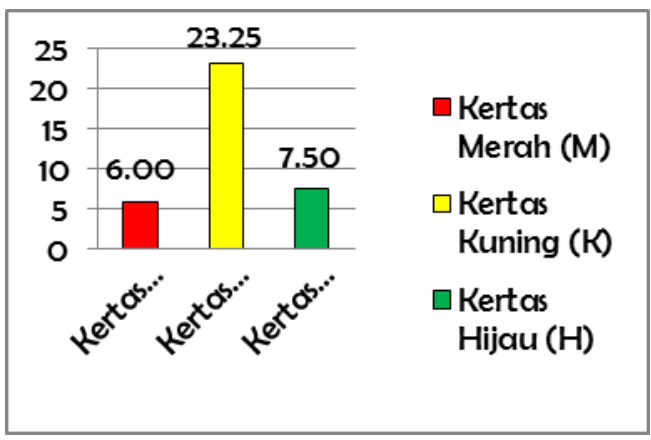

Gambar1. Populasi serangga yang terperangkap pada media kertas merah, kuning, dan hijau.

Hasil analysis of variance menunjukkan perlakuan kertas kuning dan lampu kuning berbeda nyata (significant) pada taraf $\alpha 0,05 \%$ hasil uji LSD gambar 1 . Berdasarkan uji lanjut LSD perlakuan kertas kuning (K) berbeda nyata dengan perlakuan kertas merah (M) dan perlakuan kertas hijau $(\mathrm{H})$ pada taraf 0,05 \% uji LSD.

Spesies serangga yang tertangkap pada media kertas $(\mathrm{M}),(\mathrm{K}),(\mathrm{H})$ setelah dilakukan identifikasi sebagai berikut: Ostrisnia furnacalis (Lepidoptera : Noctuidae); Helicoverpa armigera Hubner (Lepidoptera : Noctuidae); Spodoptera litura (Lepidoptera: Noctuidae); Atherigona reversura (Diptera: Muscidae); Peregrimus maidis (Homoptera: Delphacidae). Berdasarkan hasil pengamatan di lapangan tidak ditemukan pilihan warna secara spesifik untuk masing-masing spesies serangga. Dari hasil pengamatan jumlah serangga yang tertangkap pada kertas kuning jauh lebih tinggi bila dibandingkan dengan kertas warna hijau dan warna merah.

Ketertarikan serangga terhadap warna disebabkan pemantulan cahaya kesegala arah dan banyak serangga pemakan tumbuhan menanggapi positif pola pantulan cahaya dari tanaman inang, dan tanggapan ini bisa sangat spesifik. Menurut Prokopy dan Owens (1983) dalam Blackmer et al., (2008) substrat yang memantulkan cahaya secara maksimal antara 500 dan 580 $\mathrm{nm}$. Ketertarikan serangga terhadap warna kuning cenderung lebih tinggi dapat disebabkan adanya kemiripan warna polen bungan menjelang masak. Warna kuning akan memberikan stimulus terkait dengan perubahan warna pada tanaman menjelang bergunga dan pemasakan buah, dimana reflektasi maksimal dari spectrum yang terpantau oleh serangga (Prokopy dan Owens, 1983. dalam Blackmer et al., 2008).

Braham (2014) menyebutkan efek dari warna perangkap akan memberikan daya tarik $T$. absoluta jantan; kami berhipotesis bahwa warna perangkap akan lebih efektif bila diberikan feromon sebagai umpan balik. 
Roubos dan Liburd (2008) dalam Braham (2014) melaporkan perbedaan yang signifikan terhadap efek warna ember trap pada penangkapan serangga jantan penggerek akar anggur Vitacea polistiformis (Harris) (Lepidoptera : Sesiidae) menggunakan feromon seks sintetik. Lebih lanjut Braham (2014) menjelaskan, perangkap warna hijau dan kuning efektif digunakan untuk perangkap serangga, pada kondisi seperti ini tidak ditemukan perbedaan pemilihan warna berdasarkan jenis kelamin serangga.

Ostrinia furnacalis Guenee (Lepidoptera: Crambidae) merupakan hama penggerek jagung yang tersebar luas di kawasan Asia. Kemampuan merusak mencapai 98\% (Abdullah dan Rauf, 2011). Menurut Lopez et al., (2014) O. furnacalis menyukai jagung pada fase pembungaan yang mana serangga betina menempatkan telurnya pada rambut tongkol, setelah telur menetas larva akan masuk merusak biji dan tongkol. Berdasarkan hasil pengamatan di lapangan O. furnacalis populasinya meningkat pada musim hujan, sedangkan pada musim kemarau intensitas serangan sangat rendah.

Helicoverpa armigera Hubner, 1809 (Lepidoptera : Noctuidae) spesies-speies yang tersebar di seluruh dunia, antara lain: $H$. armigera Hubner, $\mathrm{H}$. obsolete Fabricius, H. conferta, $H$. fusca Hardwick. H. uniformis. Lebih lanjut Delattre dan King (1994) telur berwarna bening ditempatkan secara berkelompok, larva berwarna hijau, masa pupa warna coklat yang ditempatkan di dalam tanah, masa aktif pada musim hujan, tanaman inang jagung. Menurut Tuliabu et al., (2015) hama penggerek tongkol jagung $H$. armigera Hubner tersebar luas di pertanaman jagung mencapai $25 \%$ di Kabupaten Bone, Provinsi Gorontalo.
Spodoptera litura Fab. (Lepidoptera: Noctuidae) merupakan hama polyphagous yang menyerang banyak jenis tanaman seperti jagung, kedelai, kapas, tomat dan telah dilaporkan mencapai 150 spesies yang tersebar di seluruh belahan dunia (Kranthi et al., 2012). Menurut Singh et al., (2015) S. litura Fabricius juga menyerang kacang tanah, jagung, dan tanaman hias. S. litura aktif malam hari dan pada siang hari larva bersembunyi di dalam tanah.

Bactrocera dorsalis (Diptera : Tephritidae) terdapat beberapa spesies yang menyerang pertanaman antara lain: $B$. dorsalis, B. umbrosus, B. albistrigatus, B. cucurbitae (Marikun et al., 2014). Berdasarkan hasil penelitian Sunarno dan Stefen (2013) beberapa spesies yang tersebar di Indonesia, diantaranya: $B$. carambolae, B. Musae, B. cucurbitae, B. curifera, dan $B$. dorsalis. Tanaman inang dari masing-masing Bactrocera spp, antara lain delima, mangga, jeruk, papaya, tomat (Kuyama, 1989). Menurut Weems et al., (2015) B. dorsalis tersebar menyerang tanaman buah di wilayah Asia.

Atherigona reversura (Diptera : Muscidae) merupakan wereng tanaman jagung yang banyak ditemukan di lokasi penelitian. Tingginya populasi $A$. reversura disebabkan kondisi cuaca dan iklim selama penelitian berada pada kondisi tidak ditemukan curah hujan dari bulan Juli sampai Agustus 2016. Alasan lain tingginya populasi $A$. reversura di lokasi penelitian masih banyak ditemukan inang alternatif dari hama tersebut, sehingga mereka dapat bertahan hidup lebih lama. Ribeirio et. al. (2016) melaporkan ada enam spesies yang tersebar di berbagai negara, diantaranya: Atherigona nigritibiella Fan \& Liu, 1982., A. orientalis Schiner, 1868., A. oryzae Malloch, 1925., A. reversura Villeneuve, 1936., A. 
seticauda Malloch, 1926., A. theodori Henning, 1826. Atherigona spp menyerang tanaman pada fase generatif sehingga dapat menurunkan produksi mencapai $80 \%$, serangan awal pada saat tanaman berumur 2-5 hari yang dapat menyebabkan kematian tanaman (Pabbage et al., 2015).

Peregrinus maidis (Homoptera: Delphacidae) merupakan wereng yang menyerang tanaman jagung. Menurut Alviar et al., (2015) P. maidis selain sebagai hama tanaman jagung juga dapat berperan sebagai vector Maize Mosaic Virus (MMV) yang merupakan patogen penting pada tanaman jagung, potensial penyebaran MMV dari $P$. maidis mulai stadia larva sampai imago.

\section{Pengamatan malam hari}

Hasil pengamatan pada perangkap lampu kuning rata-rata 28,25 populasi, merah 19,25 populasi, hijau 9,50 populasi (Gambar 2).

Hasil analisis of variance menunjukkan semua perlakuan, baik lampu kuning, lampu merah dan lampu hijau berbeda nyata antarperlakuan (significant) pada taraf $\alpha$ 0,05\% (Gambar 2).

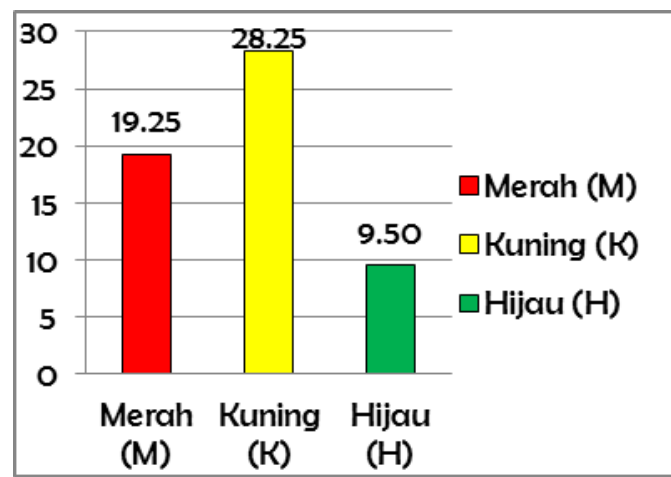

Gambar 2. Populasi serangga yang tertangkap pada, lampu kuning, merah dan hijau.
Spesies serangga yang tertangkap pada lampu kuning, merah dan hijau setelah melakukan identifikasi adalah sebagai berikut: Cylas formicarius (Coleoptera : Curculionidae); Monochilus sexmaculatus (Coleoptera : Coccinelidae); Ophimia phaceoli (Diptera : Agromizidae); Atherigona reversura (Diptera : Muscidae); Bactrocera dorsalis (Diptera : Tephritidae); Leptocoriza acuta (Hemiptera : Alydidae); Nezara viridula (Hemiptera : Miridae); Peregrimus maidis (Homoptera: Delphacidae); Aphis maidis (Homoptera : Aphididae); Valanga nigricornis (Orthropter: Acrididae); Locusta migratoria (Orthroptera : Acrididae); Gryllus mitratus (Orthroptera : Gryllidae); Gryllotalpha Africana (Orthroptera : Gryllotalpidae); Paphilium parsicum (Hymenoptera: Pamphilionidae).

Berdasarkan pengamatan di lapangan dari masing-masing spesies serangga tidak menunjukkan preferensi secara spesifik terhadap warna yang dicobakan. Hasil pengamatan juga menunjukkan tidak semua hama utama tanaman jangung yang terperangkap pada lampu warna, hal ini disebabkan adanya tanaman campuran dalam ekosistem yang sama, seperti ketela rambat, kacang tanah, terong, cabai, dan juga tanaman buah-buahan.

Cylas formicarius (Coleoptera : Curculionidae) serangga ini menyerang umbi kentang, bengkuang, ubi kayu, dan ketela rambat. Siklus hidup C. formicarius 35-40 hari, terdapat 3 instar larva dengan waktu masing-masing instar berkisar antara 21-35 hari, fase telur 7-10 hari (Nonci, 2005). Telah lama dilaporkan (Kalshoven, 1981) merupakan hama utama ubi jalar di penyimpanan mencapai 30\% (Mauludiana et al., 2015). Menurut Mansaray et al., (2015) spesies lain dari Cylas spp adalah Cylas puncticollis yang menyerang kentang. 
Cocinellidae kumbang dari ordo Coleoptera yang terdapat pada tanaman pangan baik sayuran maupun buah-buahan. Keberadaan kumbang Cocinelid ini baik sebagai predator maupun sebagai hama. Cocinelidae oleh masyarakat dikenal dengan nama kumbang helem karena bentuknya seperti helem. Coccinelidae kebanyakan sebagai predator aphis pada tanaman. Menurut Wagiman (1987) salah satu spesies dari kumbang helem Menochilus sexmaculatus efektif mengendalikan kutu hitam pada tanaman jagung atau kacang panjang.

Ophimia phaseoli (Diptera : Agromizidae) masyarakat lebih mengenal dengan nama lalat bibit. Serangga ini menyerang tanaman pada saat pem-bentukan daun lembaga. Menurut Jorani et al., (2016) Liriomyza trifolii (Burgess, 1880) juga dari ordo Diptera, famili Agromizidae merupakan serangga phytophagus yang tersebar luas di seluruh dunia. Lebih lanjut Jorani et al., (2016) menambahkan, telah dilaporkan bahwa jumlah spesies yang telah diidentifikasi sebanyak 2.500 spesies, rentangan sayap $1 \mathrm{~mm}$, ukuran maksimum $6,5 \mathrm{~mm}$, masa peletakan telur 2-5 hari jika temperatur sesuai, masa larva 4-7 hari. Siklus hidup 18-24 hari pada temperatur $24^{\circ} \mathrm{C}$.

Spesies lain dari lalat bibit ini adalah Atherigona sp. Hama ini menurut Pabbage et al., (2015) meletakkan telur satu per satu di bawah permukaan daun, waktu peletakan telur pada malam hari. Larva terdiri dari tiga instar dengan lama stadia larva secara keseluruhan 6-18 hari. Masa pupa istirahat pada pangkal batang di dalam tanah dengan lama masa pupa 5-12 hari, imago berukuran 2,5 mm-4,5 mm, imago betina meletakkan telur 3-5 hari setelah kawin dengan jumlah telur mencapai 70 butir. Siklus hidup 21-28 hari.

Bactrocera dorsalis (Diptera : Tephritidae) telah dilaporkan 50 spesies tersebar luas di kawasan Asia. B. dorsalis banyak ditemukan di Sri Lanka, India, Indoesia, Philippines (Drew dan Hancock, 1994). Tanaman inang mangga (Magnifera indica), papaya (Carica papaya), pisang (Musa paradisiaca). Lebih lanjut Drew dan Hancock (1994) menambahkan, bahwa serangga betina menempatkan telurnya pada kulit buah, telur akan menetas dalam waktu 1-3 hari, masa larva aktif makan 9-35 hari, perkembangannya dapat berlangsung pada suhu $13^{\circ} \mathrm{C}$, masa pupasi berlangsung 1-2 minggu, $B$. dorsalis dapat bertahan hidup pada suhu $7^{\circ} \mathrm{C}$, dan akan mati pada suhu $2^{\circ} \mathrm{C}$.

Menurut Weems et al., (2015) B. dorsalis tersebar di Asia, seperti Bangladesh, China, Hong Kong, India, Indonesia, Myanmar, Nepal, Taiwan, Vietnam. Deskripsi serangga dewasa panjang badan $8,0 \mathrm{~mm}$, rentangan sayap 7,3 $\mathrm{mm}$, warna tubuh bervariasi, yang ditemukan di Indonesia warna tubuh kuning dengan bagian abdomen menonjol sampai 2 ruas. Telur berwarna bening dengan ukuran $1,17 \times 0,21 \mathrm{~mm}$, tipe larva maggot seperti larva lalat pada umumnya. B. dorsalis menyerang tanaman buah-buahan dan sayuran (Anonimus, 2014). Selain sebagai hama pada tanaman $B$. dorsalis juga sebagai vektor Escherichia coli yang merupakan penyakit pencernaan pada manusia (Sunarno dan Stefen, 2013).

Leptocoriza acuta Thunb. (Hemiptera: Alydidae) pertanaman padi di Asia kerusakan didominasi oleh L. acuta, $L$. oratorius, L. varicornis, L. chinensis (Jahn et al., 2004). Di antara mereka dapat bertahan hidup pada rerumputan sebagai tempat berlindung sementara selama tanaman padi 
tidak ada ditanami. Kerusakan disebabkan L. acuta mencapai $10 \%-20 \%$ dari total tanaman yang dibudidayakan (Dutta dan Roy, 2016). Lebih lanjut Dutta dan Roy (2016) menambahkan siklus hidup L. acuta mulai dari telur, larva instar 1-6, dan imago dapat bertahan hidup pada selain tanaman pokok.

Nezara viridula (Hemiptera : Miridae) merupakan serangga penghisap cairan tanaman, bersifat cosmopolitan yang mendominasi tanaman kacang-kacangan. Karena sifatnya dapat menyerang semua tanaman, hama ini juga ditemukan pada tanaman jagung, dan kacang-kacangan. Deskriptif dan sistematik, Phylum Arthropoda, klas insekta, ordo heteroptera, family pentatomidae, genus Nezara viridula Linneus 1758, nama umum kepik hijau (Grozea, 2012). Lebih lanjut Grozea (2012) menambakan, secara morfologi kepik dewasa warna hijau, kuku berwarna coklat, scutellum berbentuk segitiga yang merupakan ciri khas hemiptera, abdomen larva terdapat bintik putih dengan warna dasar abdomen coklat.

Menurut Dyer et al., (2014) distribusi serangga ini kawasan Asia, Afrika, Eropa, dan timur tengah. Telur berwarna putih yang ditempatkan berkelompok dengan jumlah antara 30-130 butir, siklus hidup 6570 hari, telur akan menetas setelah 5 jam, kemampuan merusak sangat luas pada tanaman buah dan sayuran.

Peregrinus maidis (Homoptera: Delphacidae) selain sebagai hama pada tanaman sayuran juga dapat berperan sebagai vektor virus. Penghisap batang jagung $P$. maidis (Ashmead) merupakan vector Maize Mosaic Rhabdovirus (MMV) yang merupakan penyakit penting pada tanaman jagung dan sorghum (Alviar et al., 2016). P. maidis, Dalbulus maidis sebagai vektor virus pada tanaman pertanian dapat dikendalikan dengan menggunakan fungi entomopathogenik, seperti Beuveria bassiana, Matharhizium anisopliae, Bacillus amyloliquefacien, B. pumilus, dan B. subtilis (Toledo et al., 2015).

Aphis maidis (Hemiptera : Aphidae) nama lain Aphis glycines (Matsumura) (Hemiptera : Aphididae) merupakan serangga penghisap polong pada tanaman kedelai, cucurbitae, graminae, jagung, padi, dan sorgum (Behrens et al., 2015). Pengendalian di lapangan dapat dilakukan dengan menggunakan perangkap lampu maupun perangkap kertas yang berperekat. Menurut Rebenatto et al., (2015) hama tanaman cereal Aphids (Hemiptera : Aphididae) merupakan hama paling potensial pada tanaman pertanian. Selain sebagai hama aphids juga dapat berperan sebagai vector seperti cereal yellow virus (CYDVs), yellow dwarf disease (YDD) (Parizoto et al., 2013).

Locusta migratoria (Orthroptera : Acrididae) belalang merupakan serangga tropis padang rumput yang tersebar luas di benua Asia, Indonesia, Cina, Bangladesh dengan kerugian mencapai 20.000.000 hektar lahan padang rumput (Sun et al., 2015). Lebih lanjut Sun et al., (2015) menambahkan jenis belalang yang banyak ditemukan pada pertanaman dan padang rumput antara lain dari Famili Acididae, subfamily Acridinae, species Acrida cinerea (Thunberg), Acrida oxycephala (Pallas). Subfamily Catantopinae, spesies Dericorys annulata roseipennis (Redt.), Calliptamus barbarous cephalotes Costa. Family Tetrigidae, subfamily Tetriginae, spesies Tetrix japonica (Bol.), Tetrix tartara (Bol.). Menurut Arya et al., (2015) kelimpahan Ordo Orthroptera di daerah pengunungan Himalaya, family Acrididae: spesies Oedipoda Himalayan (Uvarov), Xenocatan- 
tops karnyi (Kibry), Aulacobothrus lueips (Walk), Gastrimargus transverses (Thun), dan family Tettigonidae: Mecapoda sp, Elimaea sp, Himertula kinneari (Uvarov).

Belalang Locusta migratoria, serangga betina dapat menghasilkan telur mencapai 270 butir dan akan menetas setelah 17 hari, nimpa mengalami 5 instar sebelum imago, lama stadium nimpha 38 hari, siklus hidup 76 hari, dalam setahun dapat menghasilkan 4-5 generasi (Pabbage et al., 2015). Berdasarkan hasil penelitian Siregar et al., (2014) nilai indeks keragaman serangga pada tanaman jagung dengan nilai $\mathrm{H}^{\prime}$ sebesar 2,368 dengan nilai keragaman sedang.

Spesies Valanga nigricornis (Orthroptera : Acrididae) juga mendominasi ekosistem pertanaman jagung di daerah pengamatan: jenis-jenis yang ditemukan antara lain, Phlaeoba antennata (Brunner), Phlaeoba infumata (Brunner). Menurut Tan dan Kamaruddin (2014) serangga dari Ordo Orthroptera tersebar luas di benua Asia yang mendominasi habitat padang rumput, lahan pertanian, dan hutan belantara. Family yang dapat menempati berbagai ekosistem antara lain Tetrigidae, Acrididae, Ensifera, Tettigonidae, Gryllidae.

Gryllus mitratus (Orthroptera : Gryllidae), Gryllotalpha aficana (Orthrop-tera : Gryllotalpidae) merupakan hasil pengamatan di lapangan selama penelitian ditemukan dua spesies, yaitu Gryllus mitratus dan Gryllotalpha aficana. Berdasarkan hasil penelitian Gupta (2016) dari family Gryllidae, subfamily Gryllinae, genus Modicoggryllus (Chopard-1961), M. confirmatus (Walker-1859), family Tettigonidae, subfamily Conocephalinae, ganus Conocephalus (Thunberg-1815), Anisoptera (Letreille-1829), Conocephalus maculatus, Hexacentrus inicolor (Serville-1831).
Lebih lanjut Gupta (2016) Famili Acrididae, subfamily Acridinae, genus Acrida (Linneus-1758), Acrida exaltata (Walker1859), Truxalis exaltata (Walker-1859), Acrida gigata, Acrida turita, Phlaeoba infumata (Brunner-1893), Phlaeoba pantili (Bolivar-1902), Calliptamus panteli (Bolivar1902), Calliptamus barbarous barbarous (Costa-1836).

Paphilium persicum (Hymenoptera : Pampilionidae) jenis predator serangga hama yang terperangkap pada media kertas dan lampu perangkap. $P$. percicum ini efektif mengendalikan Aphis maidis yang menyerang tanaman jagung. Nama lain dari $P$. percicum ini adalah tawon laba-laba (spider wasps) dari ordo hymenoptera, family Pompilidae. Telah dilaporkan Pitts dan Joseph (2007) terdapat 5 spesies di Fiji, yaitu: Anoplius caerulescence (Dalla Torro), Dendropompilus vatiensis (Williams), Anoplius elatus (Smith), Anoplius vitiensis (Williams), Cyphononyx vitiensis (Turner), Heterodontonyx guerini. Menurut Russell (2014) tercatat hampir 5000 spesies tawon laba-laba (spider wasps) Kolumbia, diantaranya: Famili Pompilidae, sub family Pepsinae, genus Ageniella, spesies accepta (Cresson), blaisdelli (Fox), coronata (Banks), euphorbiae (Viereck), gresea (Townes). Genus Alloporus, spesies pulchellus (Banks). Genus Auplopus, spesies Auplopus architectus (Say), A. caerulescens (Walsh), A. nigrellus (Banks), Genus Cadiadurgus, spesies C. hyalinatus (Fabricius).

\section{KESIMPULAN}

Ada pengaruh perangkap media kertas dan lampu warna kuning, hijau, dan merah terhadap kehadiran serangga pada pertanaman jagung. Warna kuning yang paling disukai serangga. Kertas warna cocok 
digunakan untuk memonitor serangga pada siang hari, sedangkan untuk memonitor serangga pada malam hari cocok digunakan perangkap lampu warna.

\section{UCAPAN TERIMA KASIH}

Penulis berterima kasih kepada lembaga penelitian dan pengabdian kepada masyarakat, Universitas Serambi Mekkah, Banda Aceh, tim peneliti, dorongan dan dukungan mereka dalam melaksanakan penelitian ini.

\section{DAFTRA PUSTAKA}

Abdullah, T, A. Rauf. 2011. Karakteristik Populasi dan Serangan Penggerek Jagung Asia Ostrinia furnacalis (Lepidoptera : Pyralidae) dan Hubungannya Dengan Kehilangan Hasil. J. Fitomedika, 7:175181.

Alviar, K.B., M.R. Girly, R. Doristh, R.E.W. Anna. 2016. Analysis of Acquisition and Titer of Maize Mosaic Rhabdovirus in Its Vector, Peregrinus maidis (Hemiptera : Delphacidae). J. Insect Science, 16(1) : 14-18.

http://jinsectscience.oxfordjournals.org.

Alviar, K.B., M.R. Girly, R. Dorith, E.W. Anna. 2015. Analysis of Acquisition and Titer of Maize Mosaic Rhabbovirus in Its Vector, Peregrinus maidis (Hemiptera: Delphacidae). J. of Insect Science, 16(1): 1-8. Oxford.

Andrewartha, H.G dan L.C. Birch. 1961. The Distribution and Abudance of Annimals. The University of Chocago Press. Chicago.

Anonimus, 2014. Bactocera dorsalis (Diptera : Tephritidae). Data Sheets on Quarantine Pest.
Arya, M.K., P.C.Joshi, P.B.Vinod. 2015. Species composition, abundance, density and diversity of grasshoppers (Insecta : Orthroptera) in a protected forest ecosystem in the western Himalaya. J.Fauna and Biological studies, 2(5): 4246. Open access www.faunajournal.com

Augul, R.S., H.H. Al-Saffar, N.M. Nassree. 2015. Original Article: Survey of Some Hemiptera pecies Attracted to Light Traps. Advances in Bioresearch, 6(2): 122-127. www.soeagra.com

Behrens, N.S., Z. Junwei, R.C. Joel. 2012. Pan Trapping Soybean Aphids (Hemiptera : Aphididae) Using Attractants. J. Economic Entomology, 105(3): 890-895.

Bleckmer, J.L., A.B. John, R.S. Casar. 2008. Evaluation of Color Traps for Monitoring Zygus spp.: Design, Placement, height, time of day, and non target effect. J. Crop Protection. Science Direct, 27: 171181.

Borror., Dellong. 1987. Pengenalan Serangga (edisi. Terjemahan).Universitas Indonesia Press. Jakarta.

Braham, M. 2014. Role of Trap Colors and Exposure Time of Pheromone on Trapping Efficacy of Mles of The Tomato Leafminer Tuta absoluta Meyric (Lepidoptera : Gelechiidae). J. Academic, 9(29): 2263-2271.

Chu, H.F. 1978. How To Know The Immature Incects. Zoology Institute. Lowa Wesleyon College.

Debeach, P. 1979. Biological Control by Natural Enemies. Cambrige University Press. London.

Delattre dan King. 1994) Helicoverpa armigera (Lepidoptera : Noctuida). www.bugwood.org. akses 11 Agustus 2016. 
Drew, R.A.I., D.L. Hancock. 1994. The Bactrocera dorsalis complex of fruit files in Asia. Bulletin of Entomological Research. No. 2. CAP International, Wallingford. United Kingdom.

Dutta, S., dan Roy. 2016. Life Table and Populastion Dynamics of a Major Pest Leptocorisa acuta Thunb (Hemiptera : Alydidae) on Rice and non Rice System. J. Pure App.Biosci, 4(1): 199-207. On line www.ijpad.com

Dyer, A.G. and E.G. Jair. 2014. Color Difference and Memory Recall in Free Flying Honeybeens. Journal Insects, 5:629-638.

Gomez, K.A. dan A.A. Gomez. 1995. Prosedur Statistik Untuk Penelitian Pertanian. Edisi ke dua. Universitas Indonesia (UI-Press). Jakarta.

Grozea, I., S. Ramona, M.V. Ana, A. Carabet, L. Molnar. 2012. Southern Gree Stink Bugs (Nezara viridula Linn.) A New Pest of Tomato Crops in Western Romania. J.Agric.Science, 44(2): 24-27. Romania.

Gupta. 2016. Records of Orthroptera (Insecta) Fauna from Surguja District, Chattisgarh. J. Entomology and Zoology, 4(2): 258-263.

Hendarsih dan Usyati, 1999. Perangkap Feromon Seks Untuk Penggerek Batang Padi Kuning Scirpophaga incertulas. Jurnal Perlindungan Tanaman Indonesia. Volume 5 No.2. halaman 77-100. Jurusan Hama dan Penyakit, Universitas Gadjah Mada, Yogyakarta.

Jahn, G.C., L. Domigo, M. Liberty, P. Almazan, J. Pacia. 2004. Effect of Rice Bug Leptocorisa oratorius (Hemiptera : Alydidae) on Rice Yield, Grain Quality and Seed Viability. J.Economic Entomology, 97(6): 1923-1927.
Jorani, R.A., K.F. Sawsan, A.A. Shayma, H.A. Hanaa. 2016. New Record of Liriomyza trifolii (Burgess, 1880) (Diptera : Agromyzidae) in Bagdad. J. Curr. Microbiol, 5(5): 205-211. Bagdad Iraq.

Kalshoven, L.G.E. 1981. Pest of Crops in Indonesia. PT. Ikhtiar Baru. Jakarta.

Kasumbogo, U. 1984. Analisis Ekonomi Pengendalian Hama Terpadu. Andi Ofset. Yogyakarta.

Kranthi, K.R., D.R., Jadhav, R.R. Wanjari, R. Ali. 2012. Insecticide Resistansce in Five Major Insect Pests of Catton in India. J.Crops Protection, 21:449-460.

Lopez, Y.F., T.Y. Andi, Wijaksono, Subiadi. 2014. Pola Sebaran Kelompok Telur Ostrinia furnacalis Guenee (Lepidoptera : Crambidae) Pada Lahan Jagung. J. Entomologi Indonesia, 11(2): 81-92.

Mansaray, A., A.J. Sundufu, M.T., Moseray, S.N. Fomba. 2015. Sweet Potato Weevil (Cylas puncticollis) Boheman Infestation: Curtivar Differences and the Effect of Mulching. J.Entomology. open acces, 9:7-11.

Marikun, M., A. Anshary, Shahabuddin. 2014. Daya Tarik Atraktan dan Warna Perangkap Yang Berbeda Terhadap Lalat Buah (Diptera : Tephritidae) Pada Tanaman Mangga. J. Agrotekbis, 2(5): 454-459.

Mauludiana, S., Ludji, P.A., H. Toto. 2015. Kepekaan Bebeberapa Varietas Ubi Jalar (Ipomoea batatas L.) Terhadap Hama Cylas formicarius (Coleoptera: Curculionidae). J. HPT, 3(1): 54-60. Malang.

Nonci, N. 2005. Bioekologi Cylas formicarius (Coleoptera:Curculionidae) pada Ubi Jalar. Balai Penelitian Tanaman Serealia. Maros. 
Pabbage, M.S., A.M. Adnan, N. Nonci. 2015. Pengelolaan Hama Prapanen Jagung. Balai Penelitian Tanaman Serealea, Maros. Pp 275-304.

Parizoto, G., A. Rebonatto, J. Schons, D. Lau. 2013. Barley Yellow Dwarf virus-PAV in Brazil. J. Tropical Plant Pathology, 38:1119.

Pitts, J.P., S.W. Joseph. 2007. The Spider Wasps of Fiji (Hymenoptera : Pompilidae). Fiji Arthropods VII, edited by Neal L. Evenhuis \& Daniel J. Bickel. Bishop Museum Occasional Papers 91: 35.

Prokopy, R.J. and E.O. Owens.1983. Visual detection of plants by herbivorous insect. Annual Review, 28: 337-364.

Rahayu, S., C.T. Maryani, P. Yusnani. 2013. Pengaruh Perangkap Warna Berperekat Aroma Rempah Untuk Mengendalikan Hama Gudang Lasioderma serricorne Fabricius (Coleoptera : Anobiidae) di Gudang Tembakau. J. Agroteknologi, 1(4): 1382-1390.

Rebonato, A., R.S. Jose, L. Douglas. 2015. Temporal Changes in Cereal Aphids (Hemiptera : Aphididae) Populations in Northern Rio Grande do Sul, Brazil. J. Agriculture Science, 7(10); 71-78. www.ccsenet.org/jas

Reddy, M.R.N and S.G. Ammika. 2015. Modelling and Optimazation of Solar Light Trap For Reducing and Controling The Pest Population. International Journal of Engeenering, 3(4): 224-234. www.ijetmas.com

Ribeiro, L.D.P., C.M.N. Alexandre, J. Felipe, L.F.H. Kirstern, J.B.C. Claudio. 2016. First record of Atherigona reversura Villeneuve (Diptera:Muscidae) feeding on Bermudagrass in Brazil. J. Entomologia. http://creative commons.org/licenses/by-nc-nd/4.0
Roubos, C.R. and O.E. Liburd. 2008. Effect of Trap Color on Captures of Grape Root Borer (Lepidoptera : Sesiidae) Males and non target insect. J. Agric. Urban. Entomol. 25 (2): 99-109.

Russell, S. 2014. Checklist of The Spider Wasps (Hymoptera : Pompilidae) of British Columbia. A review.

Sermsri, N and T. Chonmapad. 2015. Solar energy-Based Insect Pest Trap. $7^{\text {th }}$ World Conference on Educational Sciences (WC2015), 05-07 February 2015, Novotel Athens Convention Centre, Greece. Science Direct.

www.elsevier.com/locate/procedia

Sihombing, S.W., P. Yuswani, U.T. Mena. 2013. Perangkap Warna Perekat terhadap Hama Capside (Cyrtopeltis tenuis Reut) (Hemiptera : Miridae) Pada Tanaman Tembakau. J. Agroteknologi, 1(4): 1352-1359.

Singh, I.K., P.R. Ragesh, G. Satish, K.S. Ashok. 2015. Oviposition behavior of tobacco caterpillar Spodoptera litura Fab. (Lepidoptera : Noctuidae) on Different Host Plant. J. Entomology and Zoology, 3(3): 40-44. India.

Siregar, A.S., D. Bakti, Z.Fatimah. 2014. Keragaman Jenis Serangga di Berbagai Tipe Lahan Sawah. J. Agrotek, 2(4): 16401647.

Sun, T., Z.Y. Liu, L.P. Qin, R.J. Long. 2015. Grasshopper (Orthroptera : Acidide) Community Composition in the Ranggeland of the Northern Slopes of the Qilian Mountains in Northwestern China. J. Insect Science, vol. 15 open access. http://jinsectscience.oxfordjournals.org. ar.

Sunarno dan P. Stefen. 2013. Keragaman Jenis Lalat Buah Bactrocera spp di 
Tabelo, Kabupaten Halmahera Utara. J. Agroorestri, VIII (4) : 270-277.

Tan, M.K., K.N. Kamaruddin. 2014. Orthroptera of Fraser Hill Peninsular Malaysia. Lee Kong Chian Natural History Museum. National University of Singapura. pp. 7-13.

Thamrin, Asikin, Najib. 2003. Eksplolasi Unsur Esensial Komponen Pengenda-lian Hama Terpadu Tanaman Lahan Rawa. Balittran. Banjar Baru.

Thangalakshmi, S., R. Ramanujan. 2015. Electronic Trapping and Monitoring of Insect Pest Troubling Agricultural Fields. International Journal Emergin Engineering Research, 3 : 206-213.

Toledo, A., L. Silvina, A. Monica, M. Anna, B. Pedro. 2015. Antagonism of entomophatogenic fungi by Bacillus spp, associated with the integument of cicadellidae and delphacids. J.
Microbiology, 18 : 91 - 97. www. im. microbios. org.

Tuliabu, R., J. Pelealu, J.B. Kaligis, M.S. Dien. 2015. Populasi Hama Penggerek Tongkol Jagung Helicoverpa armigera (Lepidoptera : Noctuidae). J. Eugenia, 21(1): 1-5.

Utami, N.A.T.A., I.K. Siadi, I.D. Nyana, S. Gede. 2014. Pengaruh Penggunaan Jaring Berwarna Terhadap Kelimpahan Serangga Aphis gossypii Pada Tanaman Cabe Rawit (Capsicum frutescent L.). J. Agroteknologi Tropika, 3(4): 251-258.

Wagiman, F.X. 1987. Pengendalian Hayati. UGM. Press. Yogyakarta.

Weems, H.V., J.B. Heppner, J.L. Nation, T.R. Fasulo. 2015. Oriental Fruit Fly Bactrocera dorsalis (Hendel) (Diptera : Tephhritidae). IFAS Extension, University of Florida. //edis.ifas.ufl.edu. www.entomoljournal.com, India. 